\title{
MODIFIKASI PERILAKU TEKNIK SHAPING UNTUK MENGURANGI KECEMASAN SOSIAL PADA ANAK
}

\section{SHAPING TECHNIQUES TO REDUCE SOCIAL ANXIETY IN CHILDREN}

\author{
Winda Mulvariani', Humaira Salma Salsabiila², Muhammad Jamaluddin ${ }^{3}$ \\ Fakultas Psikologi Universitas Islam Negeri Maulana Malik Ibrahim Malang \\ windamulvariani@gmail.com
}

\begin{abstract}
In order for the child's social life to run well, appropriate with the child's psychosocial and moral development, it is necessary to immediately handle it if the child has anxiety problems in socializing with other people. So, to cope this, we can use behaviour modification shaping techniques or shaping is the development of a new operant behaviour through strengthening successive approximations, and eliminating previous approximations of this behaviour to new behaviours on the target or subject. The method of this research used with literature review. The data used in this research were obtained not directly in the field, but taking data based on previous research that has been carried out. Can be concluded that shaping techniques procedure can be done to reduce social anxiety in children. The role of parents is also very important in overcoming social anxiety in children, so that children become accustomed and do not feel anxious when they are outside, children having social anxiety will make children's growth late, due to the child's lack of social behaviour.
\end{abstract}

Keywords: early childhood, shaping techniques, social anxiety

\begin{abstract}
ABSTRAK
Agar kehidupan sosial anak berjalan dengan baik sesuai dengan perkembangan psikososial dan perkembangan moral anak, perlu segera untuk dilakukan penanganan jika anak mengalami masalah kecemasan dalam bersosialisasi dengan orang lain. Untuk mengatasi hal tersebut dapat dilakukan dengan modifikasi perilaku teknik shaping atau pembentukan merupakan pengembangan sebuah perilaku operan baru melalui penguatan aproksimasi suksesif, dan pemunahan aproksimasi sebelumnya terhadap perilaku tersebut hingga perilaku yang baru pada target atau subjek. Metode penelitian yang digunakan adalah dengan metode penelitian studi kepustakaan (literature review). Data yang digunakan pada penelitian ini didapatkan tidak langsung terjun kelapangan, tetapi mengambil data berdasarkan penelitian terdahulu yang telah dilaksanakan. Disimpulkan bahwa prosedur teknik shaping dapat dilakuakan untuk pengurangan kecemasan sosial pada anak. Peran orang tua juga sangat penting untuk mengatasi kecemasan sosial anak, sehingga anak jadi terbiasa dan tidak merasa cemas ketika berada diluar, anak yang memiliki kecemasan sosial akan membuat pertumbuhan anak menjadi terlambat dikarenakan kurangnya sosial anak.
\end{abstract}

Kata kunci: kecemasan sosial, masa anak-anak awal, teknik shaping 


\section{PENDAHULUAN}

Agar kehidupan sosial berjalan dengan sebaik mungkin, sejak dini penting untuk ditanamkan pada anak dalam memiliki sikap sosial yang baik dengan mengenalkan pada lingkungan, baik lingkungan sekitar tempat tinggal maupun lingkungan di sekolah. Masa kanak-kanak merupakan masa yang menarik untuk diteliti, masa perkembangan anak terbagi dalam empat macam perkembangan, yaitu perkembangan fisik, kognitif, emosi, dan psikososial. Salah satu macam perkembangan anak yaitu perkembangan psikososial. Perkembangan psikososial pada masa kanak-kanak mengungkap bagaimana anak-anak beradaptasi dengan orang lain, perkembangan psikososial pada anak juga mempengaruhi cara anak dalam bersosialisasi terhadap lingkungan sekitar (Jahja, 2015).

Tidak jarang, banyak anak yang masih memiliki ketakutan untuk menjalin hubungan sosial dengan orang lain, maupun teman sebayanya. Anak-anak sangat rentan mengalami kecemasan ketika berhadapan dengan lingkungan atau situasi yang baru, ataupun bertemu dengan orang-orang yang baru dikenalnya yang dianggap asing (Munfarijah, 2019). Namun, tidak semua anak takut untuk menjalin hubungan sosial dengan orang lain. Ada anak yang cepat dalam menjalin hubungan sosial dengan orang lain, ada juga anak yang lambat atau takut dalam menjalin hubungan sosial dengan orang lain. Anak yang mengalami kelambatan atau bahkan takut jika berhadapan dengan orang lain kemungkinan anak tersebut mengalami kecemasan sosial. Kecemasan sosial adalah kondisi ketika individu merasa takut untuk berinteraksi dengan orang lain dalam suatu lingkungan bahkan takut jika dinilai negatif oleh orang lain (Ehmke, 2021).

Dalam sudut pandang teori pembelajaran kecemasan pada anak mungkin dapat berasal dari rasa takut akan penolakan dan kegagalan yang terbawa dalam berbagai keadaan, baik pada keadaan sosial maupun keadaaan prestasi (Nevid, Rathus, \& Greene, 2014). Agar kehidupan sosial anak berjalan dengan baik sesuai dengan perkembangan psikososial dan perkembangan moral anak, perlu segera untuk dilakukan penanganan jika anak mengalami masalah seperti pemaparan diatas. Salah satu cara yang dapat digunakan untuk mengurangi atau bahkan mengubah perilaku kecemasan sosial pada anak yaitu modifikasi perilaku. Modifikasi perilaku merupakan sebuah upaya atau teknik yang dapat dilakukan untuk mengubah perilaku individu yang tidak adaptif menjadi lebih adaptif yang didasarkan pada teori belajar dalam sudut pandang psikologi behavioristik (Martin \& Pear, 2015). 
Modifikasi perilaku memiliki dua tujuan yang mendasar, yaitu 1) modifikasi perilaku dapat mendukung dan mempromosikan (meningkatkan) perilaku-perilaku yang adaptif, yaitu perilaku yang dapat diterima oleh masyarakat dan cenderung bermanfaat untuk perkembangan individu itu sendiri; 2) modifikasi perilaku bertujuan menekan atau menghilangkan perilaku yang maladaptif, yaitu perilaku yang cenderung tidak diterima oleh masyarakat, dan perilaku tersebut dapat merugikan perkembangan individu itu sendiri.

Salah satu teknik modifikasi perilaku tersebut yaitu teknik shaping. Teknik shaping atau pembentukan merupakan pengembangan sebuah perilaku operan baru melalui penguatan aproksimasi suksesif, dan pemunahan aproksimasi sebelumnya terhadap perilaku tersebut hingga perilaku yang baru pada target atau subjek (Martin \& Pear, 2015). Dengan teknik shaping diharapkan perilaku yang bersifat maladptif dapat berkurang atau bahkan tiada dan memunculkan perilaku baru yang lebih adaptif.

Oleh karena itu, berdasarkan pemaparan diatas peneliti tertarik untuk mengkaji mengenai modifikasi perilaku teknik shaping dalam mengurangi kecemasan sosial pada anak-anak, serta diharapkan penelitian tersebut dapat bermanfaat bagi pembaca untuk mengetahui bagaimana kecemasan sosial pada anak dan manfaat teknik shaping dalam mengurangi kecemasan sosial pada anak.

\section{METODE PENELITIAN}

Metode penelitian yang digunakan adalah dengan metode penelitian studi kepustakaan (literature review). Penelitian pustaka merupakan penelitian yang menggunakan pustaka sebagai sumber data, pustaka tersebut dapat berupa catatancatatan seseorang, riwayat hidup, surat-surat tertulis atau informasi lainnya yang memungkinkan dapat mengungkap perilaku atau kondisi psikologis seseorang (Latipun, 2017). Dalam penelitian ini peneliti menggunakan metode penelitian studi kepustakaan dengan mengacu pada buku dan artikel penelitian terkait yang berhubungan dan mendukung tema penelitian. Proses seleksi artikel berdasarkan kata kunci "Teknik Shapping dan Kecemasan Sosial serta Perkembangan Masa Anak-anak Awal". Data yang digunakan pada penelitian ini didapatkan tidak langsung terjun ke lapangan, tetapi mengambil data berdasarkan penelitian terdahulu yang telah dilaksanakan. Sumber data 
yang digunakan adalah buku, database Google Scholar, Perpusnas, e-resources yang berupa artikel dan jurnal.

\section{HASIL PENELITIAN}

\section{Teori Dasar Teknik Shaping}

Komalasari dkk (2011) mengatakan Teknik Shaping merupakan pembentukan tingkah laku yang belum pernah muncul sebelumnya dengan memberikan penguatan (reinforcement) secara langsung dan teroganisir saat tingkah laku tersebut ditampilkan. Sedangkan Menurut Chaplin (2011) Teknik Shaping merupakan mengajarkan suatu sikap yang diinginkan dengan cara memperkuat setiap unsur tingkah laku secara sistematik atau bertahap sampai kearah tingkah laku akhir. Martin \& Pear (2015) mengatakan bahwa Teknik Shaping merupakan pengembangan tingkah laku baru dengan memberikan penguatan (reinforcement) pada prilaku yang diinginkan tampil. Konselor yang terlibat membentuk tingkah laku yang lebih yang lebih menyesuaikan (adaptif) dengan memberikan penguatan primer dan penguatan sekunder.

Menurut Miltenberger (2004) kegunaan Teknik Shaping adalah, 1) Membentuk perilaku baru yang ingin dimunculkan. 2) Menampilkan kembali perilaku yang dulu pernah muncul. 3) Mengubah beberapa tingkah laku yang di munculkan seseorang karena suatu alasan yang membahayakan.

Ada beberapa faktor yang mempengaruhi pembentukan tingkah laku menurut Komalasari dkk (2011) yaitu: 1) Tingkah laku apa yang ingin dicapai. 2) Menentukan prilaku awal agar bisa menetapkan tingkat pencapaian yang dilakukan, karena teknik shaping dilakukan secara bertahap dari tingkah laku yang ingin dituju. 3) Memilah tahapan perilaku awal bergerak hingga ke perilaku akhir.

Teknik shaping memiliki 5 aspek atau dimensi perilaku yang dapat dibentuk, yaitu 1) Topografi, merupakan gerakan-gerakan fisik yang terlibat di sebuah perilaku; 2) Frekuensi, merupakan jumlah munculnya perilaku di periode waktu tertentu; 3) Durasi, merupakan jumlah waktu bagi sebuah perilaku untuk bertahan; 4) Latensi, merupakan waktu antara pengendalian stimulus dan munculnya perilaku; dan 5) Intensitas, merupakan jumlah energi yang dikeluarkan bagi sebuah perilaku (Martin \& Pear, 2015).

\section{Kecemasan Sosial}


Dalam DSM IV-TR (2000) Kecemasan sosial merupakan perilaku manusia yang memiliki hubungan dengan ketakutan-ketakutan terhadap keadaan tertentu dan hubungan sosial yang dirasa memalukan oleh individu yang bersangkutan. Ketakutan tersebut berupa takut berbicara di depan khalayak ramai, menarik diri dari pergaulan masyarakat, tidak suka berbicara dengan orang yang tidak dikenal, serta takut untuk makan dan minum di depan orang. Ahmad dalam (Novita, 2017), Kecemasan sosial adalah individu yang yakin bahwa pendapat oranglain tentang diri mereka berbeda dengan pendapat mereka terhadap dirinya sendiri.

Aspek-aspek kecemasan sosial menurut La Grace dan Lopez (Yulius, 2010) terbagi atas tigas aspek, yaitu: 1) Ketakutan pada komentar negatif yang dilontarkan oranglain kepadanya. 2) Menghindari pekumpulan sosial yang membuatnya tertekan dalam suasana yang baru yang berhubungan dengan orang baru. 3) Menghindari perkumpulan sosial yang membuatnya tertekan pada orang yang telah individu kenal.

\section{Perkembangan Masa Anak-anak Awal}

Hurlock (2002), mengatakan bahwa ada dua periode perkembangan dalam masa anak-anak yaitu; pertama, perkembangan masa awal anak-anak yang mulai pada umur dua tahun sampai enam tahun. Kedua, masa anak-anak dari umur enam tahun hingga kematangan secara seksual mulai nampak. Mutiah dalam (Hazhira, 2010), mengatakan bahwa pada masa kanak-kanak sangat mempengaruhi kehidupan yang berkaitan erat dengan stimulus, pengembangan potensi diri dan penerimaan oleh lingkungannya.

Tugas perkembangan masa anak-anak awal menurut Hurlock (2002) adalah; 1) Mulai belajar mengerti tentang prilaku seks yang benar, maksudnya pada masa ini sangat penting untuk mengenalkan edukasi seks, karena banyak kasus anak-anak menjadikorban pelecehan seksual pada usia rentang anak-anak awal. 2) Belajar membedakaan benar dan salah. 3) Belajar mengembangkan hati nurani, sejak kecil harusnya anak-anak dibiasakan dengan nilai-nilai kebaikan, seperti berbuat baik sesama manusia dan menghargai setiap perbedaan. 4) Belajar memberi dan menerima kasih sayang, pada masa anak-anak harus diberi pengertian untuk saling menyayangi, terutama untuk anak pertama yang sering iri dengan kelahiran adiknya.

\section{Faktor-faktor yang Mempengaruhi Efektivitas Teknik Shaping}


Ada beberapa hal yang dapat mempengaruhi efektivitas atau tingkat

keberhasilan teknik shaping, yaitu sebagai berikut:

1. Menspesifikkan Perilaku Target Final. Tahap yang pertamakali dilakukan dalam teknik shaping yaitu dengan mengidentifikasi dengan jelas perilaku target final atau menentukan perilaku tujuan yang ingin dibentuk.

2. Memilih Perilaku Awal. Langkah selanjutnya yaitu dengan mengidentifikasi perilaku awal (starting behavior), hal ini bertujuan untuk menetapkan tingkat pencapaian dari perilaku awal yang sebelumnya telah dimiliki, karena teknik shaping sendiri dapat dicapai secara bertahap.

3. Memilih Langkah-langkah Pembentukan (Shaping). Pada tahap ini yaitu menentukan tahap-tahap perilaku awal menuju perilaku akhir yang ingin dicapai (target final).

4. Kemantapan Perilaku di Tiap Tahap Pembentukan (Shaping).

\section{Prosedur Teknik Shaping untuk Menangani Kecemasan Sosial}

Shaping merupakan salah satu teknik modifikasi perilaku yang berfokus pada tingkah laku (behavioral) yang bertujuan untuk membentuk perilaku yang diinginkan (perilaku target) dengan memberikan perilaku yang mendekati perilaku target (aproksimasi suksesif), sehingga terbentuk perilaku yang diinginkan. Dalam penelitian ini perilaku target yang diinginkan yaitu berkurangnya kecemasan sosial pada masa anakanak awal.

Teknik modifikasi perilaku shaping memiliki 3 prosedur tahapan, yaitu

1) menspesifikkan perilaku target final, maksudnya tujuan dari teknik shaping yaitu untuk menangani kecemasan sosial pada anak, anak-anak di harapkan berani untuk bersosialisasi dan berkomunikasi dengan orang lain; 2) mengidentifikasi respons yang dapat digunakan sebagai titik awal, yaitu teknik shaping dapat dilakukan dengan menetapkan perilaku awal, seperti tidak langsung menyuruh anak untuk langsung berani bersosialisasi dengan orang lain, awalnya anak diajarkan untuk bersosialisasi dengan teman sebayanya terlebih dahulu, walaupun perilaku ini masih jauh dengan perilaku target; 3) menguatkan perilaku awal sehingga semakin mendekati perilaku target yang diinginkan muncul, maksudnya teknik shaping dapat dilakukan secara bertahap, awalnya anak diajarkan untuk bersosialisasi dengan keluarga, setelah itu menambah lagi untuk berani bersosialisasi dengan teman sebaya, kemudian anak diajarkan untuk berani 
bersosialisasi dengan orang lain. Dengan begitu anak akan berhasil untuk mengatasi kecemasan sosial ketika berhadapan dengan orang lain.

\section{KESIMPULAN}

Dari pemaparan diatas dapat disimpulkan bahwa salah satu metode modifikasi perilaku yaitu teknik shaping dapat digunakan dalam mengurangi kecemasan sosial pada anak. Peran orang tua juga sangat penting untuk mengatasi kecemasan anak, sehingga anak jadi terbiasa dan tidak merasa cemas secara sosial ketika berada diluar, anak yang memiliki kecemasan akan membuat pertumbuhan anak menjadi terlambat dikarenakan kurangnya sosial anak.

Penelitian diatas memiliki beberapa keterbatasan dikarenakan kondisi pandemi Covid-19, oleh karena itu peneliti menggunakan metode penelitian yang terbatas, diharapkan pada peneliti selanjutnya untuk melengkapi dengan melakukan penelitian yang dilakukan dengan langsung terjun ke lapangan atau dengan melaksanakan penelitian serupa dengan metode yang berbeda, untuk mengetahui seberapa efektif teknik shaping dalam mengatasi kecemasan sosial pada masa anak-anak awal, juga sangat dibutuhkan kritik dan saran yang membangun demi perbaikan penelitian tersebut dikemudian hari.

\section{DAFTAR PUSTAKA}

American Psychiatric Association. (2000). DSM IV TR. Washington DC: American Psychiatric Association.

Chaplin, J. (2002). Kamus Lengkap PSikologi. Jakarta: PT. Raja Grafindo Persada.

Ehmke, R. (2021, April 13). What is Social Anxiety. Retrieved from CHILD MIND ISNTITUTE: childmind.org

Hazhira, Q. (2010). Optimalisasi Pendidikan Anak Usia Dini Melalui Pembelajaran yang Berbasis Perkembangan Otak. Jurnal buletin Psikologi.

Hurlock, E. (2002). Psikologi Perkembangan. Jakarta: Erlangga.

Jahja, Y. (2015). Psikologi Perkembangan. Jakarta: PRENADAMEDIA GROUP.

Komalasari, \& dkk. (2011). Pembelajaran Konstektual Konsep dan Aplikasi. Bandung: PT Refika Aditama.

Latipun. (2017). Psikologi Eksperimen. Malang: UMM Press.

Martin, G., \& Pear, J. (2015). Modifikasi Perilaku. Yogyakarta: Pustaka Pelajar.

Miltenberger, R. (2004). Behavior Modification Principles and Procedures. 3th Edition. Australia: THOMSON WADSWORTH.

Munfarijah, I. (2019, September 9). Mengatasi Kecemasan pada Anak Usia Dini. Retrieved from

RUANG GURU

PAUD: 
https://anggunpaud.kemendikbud.go.id/idex.php/berita/index/201909091857 52/Mengatasi-Kecemasan-pada-Anak-Usia-Dini

Nevid, J., Rathus, S., \& Greene, B. (2014). Psikologi Abnormal. Jakarta: Erlangga.

Novita, A. (2017). Kecemasan Sosial pada Remaja yang Tinggal di Panti Asuhan di Tinjau dari Kepribadian.Skripsi. Malang: Fakultas Psikologi UMM Malang.

Yulius, B. P. (2010). Hubungan antara Konsep Diri dengan Kecemasan Sosial pada Remaja Kelas XI SMA Kristen Surakarta. Skripsi. Surakarta: Fakultas Kedokteran Universitas Sebelas Maret. 
PSYCHE: JURNAL PSIKOLOGI UNIVERSITAS MUHAMMADIYAH LAMPUNG

ISSN (electronic) 2655-6936 ISSN (printed) 2686-0430 